\section{Biomolecular mixture}

Intermolecular Interactions and Biomolecular Organisation. By A. J. Hopfinger. Pp. xviii + 395. (Wiley InterScience: New York and London, 1977.) $\$ 33$; £19.50.

NEw results in science are published and then reviewed in journals specialising in broad or narrow topics of current interest. Books should be different in that they represent a new synthesis of fact and theory collected and distilled into a coherent and useful entity. Unfortunately, we are facing a deluge of books which offer very little that has not earlier been given in closely related form. The volume under review, although attractively titled, is a compilation of disjointed topics with no visible thread leading from one to the other. One cannot hope to learn from it about the theory of solutions of macromolecules, or conformational analysis by nuclear magnetic resonance, or quantum mechanical calculations, nor can one form a critical opinion about how these connect to the problem of drug design, for instance, to which a whole chapter is devoted. I found particularly revealing the admission of the author that large portions of his book are indeed taken (p145 or p252, for instance) "from the excellent review" of other authors!

After trying to examine the extensive subject matter somewhat more closely, I am reminded of a story told by the late author, Maurice Samuel, in his quest to evaluate the widely ranging work of a famous contemporary historian. All fellow historians approached indeed acquiesced that his study of history scemed highly significant; however, as far as their own speciality was concerned, they voiced grave reservations. Trying to evaluate not only the breadth of the present work, but rather the depth to which individual topics are treated, particularly those with which I am familiar, I ran into similar difficulties. To mention a few examples only, our own work on hydration of DNA is incorrectly quoted (p160), lumped together with other quotes in purely irrelevant fashion. Concerning our work quoted in the footnote of Table 8-1, viscometry of DNA cannot be used directly to compute the number of intercalated dye molecules. On p265, part of the enormous Table $12-1$, the author reprints an incorrect finding first made in 1958 , and then often repeated, that glutamic dehydrogenase is a zinc ienzyme with a molecular weight of $1,000,000$ containing two to six $\mathrm{Zn}$ molecules. For many years now it has been known that glutamic dehydrogenase has a molecular weight of six times 56,000 and does not contain $\mathrm{Zn}$. The discussion on nucleohistone aggregation and chromatin structure in chapter 13 is largely outdated and would be unintelligible to the uninitiated. Space does not permit me to go into other examples, which abound.

The proof-reading is sloppy beyond the border of insult. Having myself recently published a book, I know how difficult it is to win the battle with publisher and printer. Yet one must try. The author is responsible that the same name is spelt Fahien, Fehiem, Fahiem on one page(152), Subivana and Subirama (the correct name is Subirana) on p204, and Schleich, Scheich and Schiech in chapter 12. There are many more such examples. A carefully proof-read name index would have been helpful in a work which draws on so many varied sources.

Henryk Eisenberg

Henryk Eisenberg is Professor of Biophysics and Head of the Polymer Department at the Weizmann Institute of Science. Rehovot, Israel.

\section{Science policy yearbook}

Science and Government Report International Almanac, 1977. Edited by Daniel S. Greenberg. Pp. 305. (Science and Government Report: Washington DC, 1977.) $\$ 54$ before 1 September; afterwards $\$ 75$.

THIs first volume in what is intended as an annual series introduces the idea of a 'science policy yearbook'. Part I consists of 20 chapters which survey, nation-by-nation, major recent developments in science and technology policy. Most authors are experienced science journalists (not a few of whose names will be well known to Nature readers), and the chapters are concise, informative and wholly unpolemical. Each covers more or less similar ground: changing priorities; research and development expenditure; changes in government research organisation and science policy advisory machinery; and issues which in the country concerned have been publicly contentious.

I personally enjoyed this part of the book and can recommend it to anyone who wants to keep broadly in touch with what is happening on the interface between science and government in a wide range of countries. Though more readable than the products of international organisations active in this field, it lacks the systematic quantitative data which often makes their reports a useful basis for further analysis.

Part 2 of the book, an international directory of major scientific organisations and science policy personnel, though commendably up to date, is curiously haphazard in its coverage. Thus, although we find listed British Departmental Chief Scientists and Britain's Scientific Counsellors overseas, the only organisations whose addresses and functions are given are the Central Policy Review Staff in the Cabinet Office, the SRC, MRC and Department of Energy.

Part 3 gives excerpts from eight recent (mostly American) science policy documents, including President Carter's campaign speeches and the NIH guidelines on recombinant DNA experiments.

On balance, the yearbook idea is an interesting one, and libraries might wish to acquire this first effort notably for the contents of Part 1.

Stuart S. Blume

Stuart S. Blume has worked on science policy issues at the OECD, the Science Policy Research Unit at the University of Sussex, UK, and in various governmental posts.

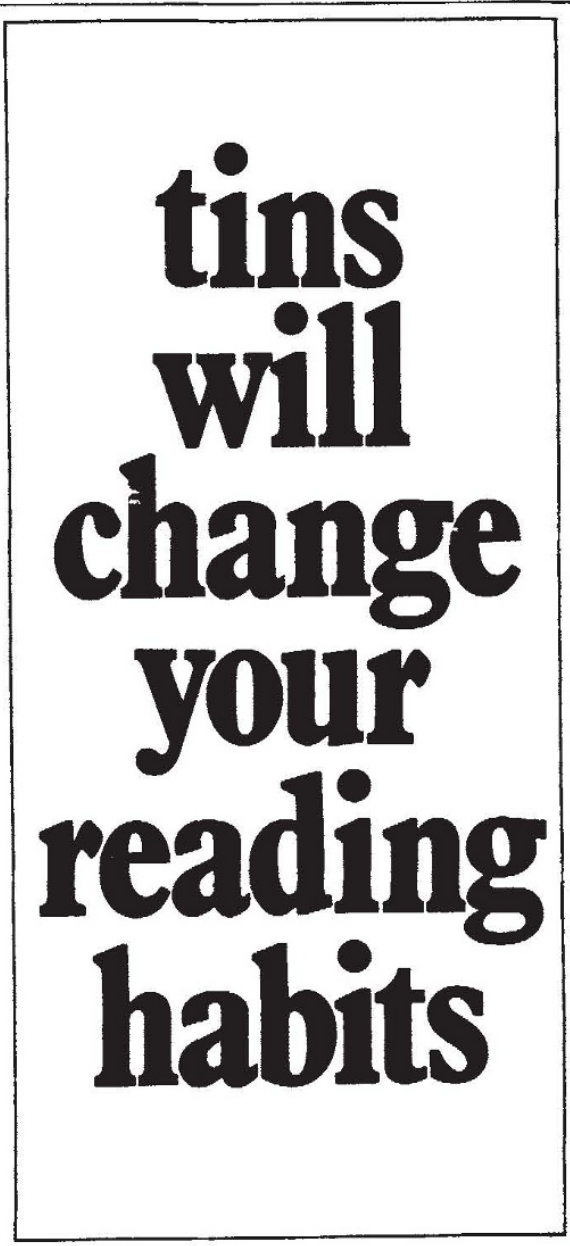

Circle No. 19 on Reader Enquiry Service Coupon. 